
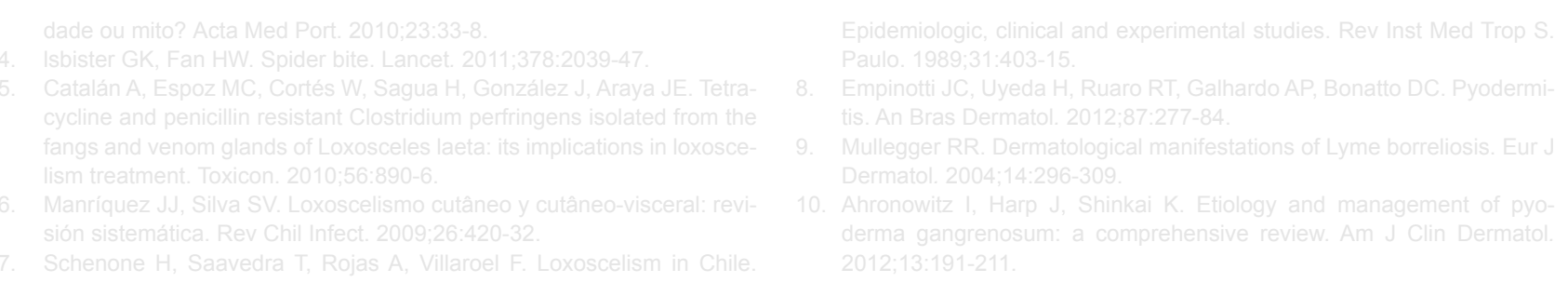

\title{
Two Cases of the Same Family with the Unusual Elevation of CA19-9 Levels
}

\author{
Dois Casos na Mesma Família com a Elevação Incomum de Níveis de CA19-9
}



\author{
Metin UYANIK ${ }^{1}$, Erdim SERTOGLU ${ }^{2}$, Muhittin A. SERDAR ${ }^{3}$, Fevzi N. AYDIN ${ }^{1}$, Taner OZGURTAS ${ }^{1}$, Ismail KURT ${ }^{1}$ \\ Acta Med Port 2014 Sep-Oct;27(5):657-660
}

\section{ABSTRACT}

Introduction: Serum carbohydrate associated antigen (CA19-9) is widely used marker in clinical practice and shows small increases in a few benign diseases. Here we report two cases, a mother and her daughter with slightly elevated CA19-9 levels not accompanied by any clinical pathology.

Case Presentation: The mother with elevated CA19-9 level (89.90 U/mL; upper limit of normal range (ULNR) $<37 \mathrm{U} / \mathrm{mL})$ was referred to our department for evaluation. Similar increase was determined in her daughter incidentally. Daughter's CA19-9 level was 123.92 $\mathrm{U} / \mathrm{mL}$. Extensive laboratory data, imaging procedures and clinical evaluations were within the normal ranges except elevated CA199 levels for both. Also, any pathology compatible with the elevated CA19-9 level couldn't be determined. In order to avoid laboratory errors and interferences, we measured the samples at four different immunoassay platforms twice.

Conclusion: Healthy people can be in excess of the ULNR. Therefore, clinicians need to be aware of these rare situations without missing the malignant disorders.

Keywords: CA-19-9 Antigen; Family; Tumor Markers, Biological.

\section{RESUMO}

Introdução: O antigénio carbohidrato (CA19-9) presente no soro é um marcador amplamente utilizado na prática clínica e apresenta pequenos aumentos em algumas doenças benignas. Aqui relatamos dois casos saudáveis, uma mãe e a sua filha, com níveis CA19-9 um pouco elevados.

Casos Clínicos: A mãe, com um nível CA19-9 elevado $(89,90 \mathrm{U} / \mathrm{mL}$; limite superior do intervalo normal (ULNR) $<37 \mathrm{U} / \mathrm{mL})$ foi encaminhada ao nosso departamento para avaliação. Um aumento semelhante foi incidentalmente determinado na sua filha. $\mathrm{O}$ nível de CA19-9 da filha era 123,92 U/mL. Os restantes parametros laboratoriais avaliados, estudos imagiológicos e avaliações clínicas revelaram-se dentro dos limites da normalidade. Não foi encontrada, qualquer patologia que justifique elevado nível de CA19-9. A fim de evitar erros de laboratório ou possíveis interferências, as amostras foram analisadas em quatro plataformas de imunoensaios diferentes, em duplicado.

Conclusão: As pessoas saudáveis podem ter níveis da CA19-9 superiores aos limites de referência. Portanto, os médicos precisam estar cientes dessas situações raras, sem falhar o diagnóstico de doenças malignas.

Palavras-chave: Antigénio CA-19-9; Família; Marcadores Biológicos de Tumor.

\section{INTRODUCTION}

The serum carbohydrate associated antigen (CA199. Sialyl Lewis-a) is a high molecular glycolipid which is a marker for both colorectal and pancreatic carcinoma, and is used in monitoring patients with these cancers in conjunction with imaging tests. ${ }^{1}$ It shows small increases in a number of benign diseases, with highest levels in pancreatic adenocarcinoma, hepatocellular and cholangiocellular cancer, and also in gastric, colorectal, and occasionally other cancers (Table 1$)^{2}$

Here we report two healthy cases, a 37-year-old mother and a 16-year-old daughter, with slightly elevated CA19-9 levels. Additionally, to ensure the awareness of subjects relevant to this topic, we detected considerable differences between CA19-9 measurements with four different immunoassay methods.

\section{CASE 1}

A 37-year-old woman who was suffering from abdominal pain and presented mildly elevated CA19-9 level was referred to our department for evaluation. Her medical

1. Department of Clinical Biochemistry. Gulhane School of Medicine. Ankara. Turkey.

2. Biochemistry Laboratory. Anittepe Dispensary. Ankara Mevki Military Hospital. Ankara. Turkey.

3. Department of Medical Biochemistry. School of Medicine. Acibadem University. Istanbul. Turkey.

Recebido: 09 de Fevereiro de 2014 - Aceite: 12 de Maio de 2014 | Copyright @ Ordem dos Médicos 2014 
Table 1 - Causes of serum CA19-9 elevation (numbers in brackets correspond to the listed references)

\begin{tabular}{|c|c|c|}
\hline \multirow{2}{*}{ Etiology } & \multicolumn{2}{|c|}{ Serum CA19-9 levels } \\
\hline & Marked elevation (> $1000 \mathrm{U} / \mathrm{ml}$ ) & Mild elevation (< $1000 \mathrm{U} / \mathrm{ml})$ \\
\hline \multicolumn{3}{|l|}{ Malignancies $^{2}$} \\
\hline Biliary tract & + & \\
\hline Pancreas & + & \\
\hline Colon & + & \\
\hline Stomach & + & \\
\hline Female reproductive system & & + \\
\hline Cholestasis $^{3}$ & + & \\
\hline Acute hepatitis $^{4}$ & & + \\
\hline \multicolumn{3}{|l|}{ Chronic liver disease $^{5}$} \\
\hline Non-alcoholic & & + \\
\hline Alcoholic & & + \\
\hline Cystic fibrosis ${ }^{6}$ & & + \\
\hline Pancreatitis $^{7}$ & & + \\
\hline Diabetes mellitus $^{8}$ & & + \\
\hline Interstitial pulmonary disease & & + \\
\hline Collagen vascular diseases ${ }^{9}$ & & + \\
\hline Endometriosis $^{10}$ & & + \\
\hline \multicolumn{3}{|l|}{ Case reports ${ }^{11-13}$} \\
\hline Hydronephrosis & & + \\
\hline Splenic cyst & & + \\
\hline Bronchogenic cyst & & + \\
\hline Hepatic steatosis & & + \\
\hline Colon diverticulitis & & + \\
\hline Hypothyroidism & & + \\
\hline Heavy tea consumption & & + \\
\hline
\end{tabular}

history was unremarkable and there was no family history of any gastrointestinal malignancy. She was a nonsmoker and denied alcohol abuse or medication intake. Also, there were no abnormal physical examination findings.

Abdominal and pelvic ultrasonography (USG), computed tomography scan, upper endoscopy and colonoscopy were performed to evaluate intra abdominal abnormalities. Examination of the respiratory system and chest X-ray were normal. There was no abnormality or malignancy compatible with the elevated levels of CA19-9.

Laboratory data demonstrated that electrolytes, liver function tests (ALT, AST), urea, creatinine, CRP, ESR, amylase, lipase, whole blood count, fasting blood glucose, triglycerides, cholesterol, ferritin and thyroid function test (T3, T4, TSH) levels were within the normal range. Serum CA19-9 level was mildly elevated $(89.90 \mathrm{U} / \mathrm{mL})$ (Table 2). Other markers, including carcino embryonic antigen (CEA), alpha-fetoprotein (AFP), CA15-3 and CA125 were all within the normal range. Homeostasis Model Assessment-Insulin Resistance (HOMA-IR) value was 1.54.

In order to avoid analytical errors and interferences, we analyzed serum sample twice at four different immunoassay platforms: UniCel ${ }^{\circledR}$ Dxl 800 (Beckman Coulter, USA), Roche Modular Analytics Elecsys E170 (Roche Diagnostics), Architect i2000SR, (Abbott Diagnostics, USA) and Advia
Centaur $^{\circledR}$ XP (Siemens Healthcare Diagnostics Inc, USA). We also performed polyethylene glycol (PEG) precipitation to assess macro-complex interference and there was no difference after PEG precipitation.

All investigations for underlying malignancy were negative. After an incidental measurement, similar increase was determined in her daughter's serum CA19-9 level.

\section{CASE 2}

Then, 16-year-old daughter with the elevated CA19-9 level was evaluated $(123.92 \mathrm{U} / \mathrm{mL}$ ) (Table 2). Her medical history was unremarkable too. She had no complaints and symptoms. Additionally, the same laboratory tests were performed twice for the daughter. They were all in the normal ranges except CA19-9. HOMA-IR value was 0.79.

Moreover, similar investigations and evaluations confirmed the absence of any malignancy even in this patient. After a gynecological consultation, young girl was diagnosed with polycystic ovary syndrome (PCOS). Pelvic USG revealed bilateral polycystic ovaries.

Second measurements for both cases were performed after 2 months from the first analysis. The recheck levels were similar to the first ones. The results are given in Table 2.

Procedures were performed in accordance with the 
Table 2 - The results of the samples of four different immunoassay platforms

\begin{tabular}{|c|c|c|c|c|c|c|c|}
\hline Method & & & & $\begin{array}{l}\text { Architect } \\
\text { i2000SR }\end{array}$ & $\begin{array}{c}\text { Advia } \\
\text { Centaur }^{\circledR} \\
\text { XP }\end{array}$ & $\begin{array}{l}\text { UniCel }^{\circledR} \\
\text { Dxl } 800\end{array}$ & $\begin{array}{c}\text { Elecsys } \\
\text { E170 }\end{array}$ \\
\hline $\mathrm{ULNR}^{*}(\mathrm{U} / \mathrm{mL})$ & & & & 37 & 35 & 35 & 35 \\
\hline \multirow{4}{*}{$\begin{array}{l}\text { Serum CA19-9 Results } \\
(\mathrm{U} / \mathrm{mL})\end{array}$} & \multirow{2}{*}{ Mother } & $\begin{array}{l}\text { CA19-9 level } \\
\text { on admission }\end{array}$ & First measurement & 59.70 & 64.90 & 28.80 & 35.80 \\
\hline & & 89.9 & $\begin{array}{l}\text { Recheck } \\
\text { measurements }\end{array}$ & 66.40 & 65.11 & 29.30 & 35.13 \\
\hline & \multirow{2}{*}{ Daughter } & $\begin{array}{l}\text { CA19-9 level } \\
\text { on admission }\end{array}$ & First measurement & 87.84 & 76.85 & 64.40 & 42.99 \\
\hline & & 123.92 & $\begin{array}{l}\text { Recheck } \\
\text { measurements }{ }^{* *}\end{array}$ & 105.40 & 78.70 & 48.60 & 51.95 \\
\hline
\end{tabular}

${ }^{*}$ ULNR: The upper limit of the normal range suggested by the manufacturers

${ }^{* *}$ Recheck measurements: Second measurement after two months from the first analysis

Helsinki Declaration (revised in 2008). Both patients have signed an informed consent.

\section{DISCUSSION}

In these cases, the usual causes of CA19-9 elevation were ruled out. Both the mother and daughter did not refer any clinical situations related to conditions that urges CA19.9 increases, and frequently encountered types of malignancy that cause these elevations were excluded. All the laboratory data, upper and lower abdominal USG, colonoscopy and chest radiography did not reveal any pathology.

Although increased CA19-9 values have also been associated with hypothyroidism, our cases were euthyroid, and hypothyroidism was also excluded. ${ }^{13}$ Because the mother did not have polycystic ovaries, PCOS was not considered as the cause of CA19-9 elevation.

Furthermore, the concentration of a tumor marker in a given specimen, determined with assays from different manufacturers, can vary due to differences in assay methods, types of antibodies and epitopes used, and reagent specificity. This was likely due to these two methods (the ADVIA Centaur and ARCHITECT i2000) use a single monoclonal antibody (1116-NS-19-9) for the 2-step sandwich immunoassay, whereas the other 2 (Elecsys E170, and UniCel DxI 800) use one or more different antibodies. Different antibodies recognize different parts of the molecule, and heterogeneity or conformational alteration of the antigens may explain inter-method differences, partially. Accordingly, standardized reagents for tumor marker assays are needed to ensure the reliability of the results from different assays, and the standardization is also important for commutability among results from different assays in order to deal with increased patient mobility between hospitals. We considered that the exact underlying explanation for elevated CA19-9 was epitopal differences.

As manufacturers specified in their test manuals,

there are healthy people with excess of the upper limit of the normal range. The upper $97.5 \%$ reference limit for all methods can differ from the manufacturers' upper limit of expected values for healthy subjects. ${ }^{14}$

Our cases highlight the importance of awareness of elevated tumor markers with no malignancies but also with benign diseases. False positives can lead to overinvestigations and cause unnecessary anxiety to patients. Our hospital was the third hospital referred for this reason in the six-month period. Because it demands a time- and resource-consuming process, it is important that patients also should know her/his personal results to avoid being investigated for the same reason again and again.

\section{CONCLUSION}

In conclusion, the clinicians need to be aware of healthy subjects with tumor marker elevation over the upper limit of the normal range and the analytical differences of methods without missing diagnoses of malignant disease as well. Therefore, more attention should be paid to these subjects and further workup should be done to establish consensus guidelines for tumor marker(s) measurements. ${ }^{15}$ Each case may not have the same characteristics, and management should be individualized.

\section{OBSERVATIONS}

The abstract entitled "Unusual CA19-9 Elevation in a 37-year-old Mother and a 16-year-old Daughter" has been accepted as a poster presentation at the IFCC EUROMEDLAB Milano 2013 Congress. (19-23 May 2013).

\section{CONFLICT OF INTEREST}

The authors declare that they have no conflict of interest.

\section{FUNDING SOURCES}

The authors declare that they have no funding sources. 
2. Lamerz R. Role of tumour markers, cytogenetics. Ann Oncol. 1999;10:S145-9.

3. Halme $L$, Karkkainen $P$, Isoniemi $H$, Makisalo $H$, von Bogulawski $K$ Hockerstedt K. Carbohydrate 19-9 antigen as a marker of non-malignant hepatocytic ductular transformation in patients with acute liver failure. A comparison with alpha-fetoprotein and carcinoembryonic antigen. Scand J Gastroenterol. 1999;34:426-31.

4. Schöniger-Hekele $\mathrm{M}$, Müller $\mathrm{C}$. The combined elevation of tumor markers CA19-9 and CA 125 in liver disease patients is highly specific for severe liver fibrosis. Dig Dis Sci. 2006;51:338-45.

5. de Goede E, Yap SH. An exceptional high concentration of serum CA 19.9 in a patient with alcoholic liver disease. Gut. 1997;41:579-80.

6. Augarten A, Berman H, Aviram M, Diver-Habber A, Akons H, Ben Tur $\mathrm{L}$, et al. Serum CA 19-9 levels as a diagnostic marker in cystic fibrosis patients with borderline sweat tests. Clin Exp Med. 2003;3:119-23.

7. Mujica VR, Barkin JS, Go VLW. Acute pancreatitis secondary to pancreatic carcinoma. Pancreas. 2000;21:329.

8. Petit JM, Vaillant G, Olsson NO, Guignier F, Collignon S, Verges B, et al. Elevated serum CA19-9 levels in poorly controlled diabetic patients. Relationship with Lewis blood group. Gastroenterol Clin Biol.
1994;18:17-20.

9. Cantagrel A, Moulinier L, Beljio K, Duffaut M, Laroche M, Bon E, et al. Elevation du CA 19.9 au cours des rhumatismes inflammatories dysimmunitaires. A propos de 6 observations. Rev Rhum Ed Fr. 1994;61:599-06.

10. Harada T, Kubota T, Aso T. Usefulness of CA19-9 versus CA125 for the diagnosis of endometriosis. Fertil Steril. 2002;78:733-9.

11. Inayama $\mathrm{Y}$, Uesato $\mathrm{M}$, Takase $\mathrm{K}$, Motono $\mathrm{N}$, Nakatani $\mathrm{Y}$, Kitamura H. Immunohistochemical study of CA19-9 and SPan-1 in cases of hydronephrosis. Urol Int. 1996;57:93-8.

12. Tekin O. Hypothyroidism-related CA19-9 elevation. Mayo Clin Proc 2002;77:398.

13. Howaizi M, Abboura M, Krespine C, Sbai-Idrissi MS, Marty O, DjabbariSobhani M. A new cause for CA19.9 elevation: heavy tea consumption. Gut. 2003;52:913-4.

14. La'ulu SL, Roberts WL. Performance characteristics of five automated CA19-9 assays. Am J Clin Pathol. 2007;127:436-40.

15. Galli C, Basso D, Plebani M. CA 19-9: handle with care. Clin Chem Lab Med 2013:51:1369-83. 


\section{Two Cases of the Same Family with the Unusual Elevation of CA19-9 Levels}

Acta Med Port 2014:27:657-660

Publicado pela Acta Médica Portuguesa, a Revista Científica da Ordem dos Médicos

Av. Almirante Gago Coutinho, 151

1749-084 Lisboa, Portugal.

Tel: +351218428215

E-mail: submissao@actamedicaportuguesa.com

www.actamedicaportuguesa.com

ISSN:0870-399X | e-ISSN: 1646-0758

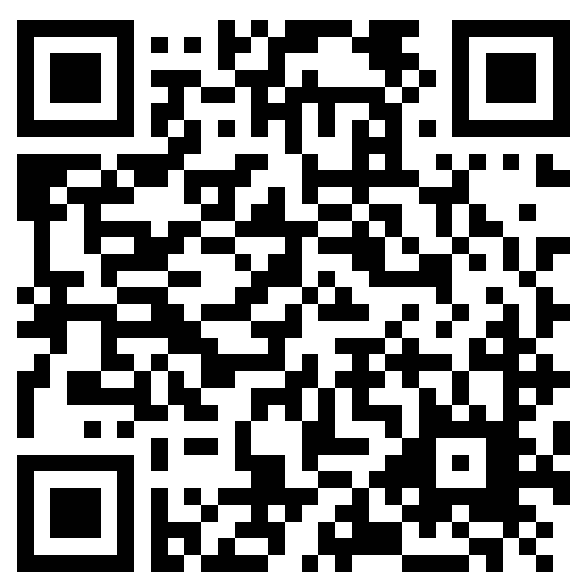

